\title{
VEHICLE SI ENGINE WITH MPI OF LIQUID STATE LPG
}

\section{STANISLAV BEROUN, PAVEL BRABEC, ALEŠ DITTRICH}

Technical University of Liberec, Studentská 2, CZ 46117 Liberec, Czech Republic; Department of Vehicles and Engines, Mechanical Engineering Faculty; Institute for Nanomaterials, Advanced technologies and Innovation

Email: stanislav.beroun@tul.cz

\section{SHRNUTí}

V úvodní části článku jsou prìpomenuty možné způsoby tvoření směsi LPG se vzduchem (vstrǐikování LPG v plynném nebo kapalném stavu) a jejich vliv na provozní vlastnosti zážehového motoru. Další kapitola vysvětluje děje, které působí na průběh vstřikování LPG v kapalném stavu do nasávaného vzduchu v sacím potrubí motoru. Pomocí zjednodušeného výpočtového modelu je ukázáno, že vstrǐkování LPG v kapalném stavu je principiálně spojeno s extrémně nízkými teplotami LPG na výtoku ze vstřikovací trysky a s rizikem tvoření námrazy na výtokové trysce a príp. i v sacím potrubí. V článku je ukázána konstrukční úprava koncové části vstriikovače LPG s potlačeným rizikem pro tvoření námrazy. Výsledky experimentálního výzkumu na zkušebním zážehovém motoru s tvořením směsi vstřikováním LPG v kapalném stavu ukazuji velmi kvalitní vlastnosti motoru. Měření průběhu tlaku LPG v koncové části vstřikovače a měření teplot na výtokové trysce potvrzují výsledky provedených výpočtů. Měření na zkušebním motoru doplňují vizualizace vstřikování LPG do sacího potrubí. $V$ závěru článku je souhrn poznatků z výzkumu tvoření směsi vstřikováním LPG v kapalném stavu do sacího potrubí motoru.

KLIČCVÁ SLOVA: ZÁŽEHOVÝ MOTOR, VSTŘIIKOVÁNÍ LPG V KAPALNÉM STAVU, VÝKON MOTORU, NÁMRAZA V SACÍM POTRUBÍ

\section{ABSTRACT}

The first part of the article reviews the possible methods for LPG and air mixture forming (injection of gaseous or liquid state LPG) and their influence on the operating properties of an SI engine. The next chapter explains the processes that take place when liquid state LPG is injected into the air flow of an internal combustion engine intake manifold. A simplified calculation is used to show that the injection of liquid state LPG is associated with extreme low temperature of the LPG injected into intake manifold and with ice formation on the outlet nozzle. The article sets out the design of an end part injector (EPI) for liquid state LPG that reduces the risk of icing of the outlet nozzle. The results of experimental research indicate very good operational properties for a vehicle SI engine with the combustion mixture formed by the injection of liquid state LPG into the engine intake manifold. The calculation results are confirmed by recording plots of LPG pressure inside the end part of injector (EPI) and the temperature on the outlet nozzle (ON) of the LPG injector. Visual inspection of injection of liquid state LPG into the intake manifold clearly supports the performed measurements. The conclusions summarize the knowledge gained from the laboratory investigation of liquid state LPG injection into an engine intake manifold.

KEYWORDS: SI ENGINE, LIQUID STATE LPG INJECTION, ENGINE POWER, ICING INSIDE INTAKE MANIFOLD

\section{INTRODUCTION}

Vehicle producers are currently focused primarily on CNG as an alternative gas fuel for SI engine powered vehicles. However, some properties of LPG remain of interest with respect to use by private car owners. In addition, there has recently been growing interest in the use of LPG for dual fuel diesel-gas engines.

The most widespread method of mixture formation for a naturally aspirated SI engine running on LPG is the injection of LPG in its gaseous state into the intake air. Such SI engines have around $5-8 \%$ lower power in comparison with an engine running on petrol. The cause of this power drop is the reduction in the fresh mass of air as a consequence of the volume of gaseous fuel in the fresh mixture. Fuel systems for injection of gaseous state LPG often have a big problem at low ambient temperatures (low LPG pressure inside the pressure tank), which complicates the engine running in wintertime.

A promising solution for a naturally aspirated $\mathrm{SI}$ vehicle engine running on LPG fuel is mixture formation by injection of LPG in its liquid state into the intake manifold. Very intensive evaporation 
of injected liquid state LPG leads to a drop in the temperature of the fresh mixture and subsequently to increased filling efficiency of the engine. This means the engine power when running on LPG is in effect equivalent to, or even slightly better than that of the engine running on petrol. However, an effect of the very low LPG temperature on the LPG injector outlet nozzle (ON) on intake manifold (the LPG temperature is between $-30^{\circ} \mathrm{C}$ and $-55^{\circ} \mathrm{C}$ ) is to cause icing on the ON of LPG injector from the humidity of atmospheric air. Fragments of ice are imported into the engine cylinder and can lead to an irregular misfire of the mixture in the engine cylinder. An SI engine with injection of liquid state LPG must therefore have a special design of EPI to prevent icing.

The fuel system for injection of liquid state LPG is less sensitive to poorly evaporating substances in LPG than LPG fuel systems using an evaporator and pressure regulator for LPG injection in the gaseous state. However, fuel systems for injection of liquid state LPG require a special fuel pump (generally inside the pressure tank) and LPG pressure regulator, needed for both LPG injection and continual LPG flow through the electromagnetic valve of the LPG injectors (to prevent formation of LPG steam bubbles inside electromagnetic valves) and the return flow of $L P G$ to the pressure tank.

Mixture formation by injection of liquid state LPG can be considered a promising approach both for $\mathrm{SI}$ engines and for dual diesel-gas engines.

\section{INJECTION OF LIQUID STATE LPG INTO THE ENGINE INTAKE MANIFOLD}

Figure 1 shows the lay-out of the liquid state LPG injector. The LPG injector consists of the electromagnetic valve (EV) which supplies the LPG charge (synchronized with the suction of the individual engine cylinders) to the end part injector (EPI) in the intake manifold of each cylinder (MPI concept). After outflow of the LPG to the EPI, there is a significant LPG pressure drop in the EPI and then very rapid vaporization. The heat energy needed for evaporation is taken from the thermal energy of the LPG feed into the EPI and to a lesser extent heat for the LPG evaporation is ambient heat transferred into the EPI. The wet LPG steam, which has a very low temperature due to the intensive evaporation of LPG in the EPI, is then injected into the inlet air. Using a simplified computational simulation of the process in the $E P I$, the relationships between the inside volume geometry of the EPI, state quantities of LPG inside the EPI and the outflow of the wet LPG steam into the engine intake manifold were investigated [1]. A brief description of the computation procedure of the LPG process in the EPI is given in the following paragraph.

The LPG charge is fed from the EV to the EPI in elementary quantities $\Delta m_{L P G / l i q}$. Within the entire volume of the channels $V_{E P I}$ before the outlet nozzle (ON), part of the LPG vaporizes and part remains in liquid state and thus a wet LPG steam arises in the EPI.
We can express the density of wet LPG steam in the volume $V_{E P I}$ as the sum of the density of LPG saturated steam and the density of the dispersed LPG liquid droplets.

$$
\rho_{L P G / E P I}=\rho_{L P G / \text { gas } / E P I}+\rho_{L P G / \text { liq } / E P I}
$$

The proportion of the vaporized LPG in $V_{E P I}$ determines the thermal balance of the LPG state inside the EPI. The density of LPG saturated steam (gaseous state) depends on the LPG pressure and temperature inside the EPI (volume $V_{E P I}$ ):

$$
\rho_{L P G / \text { gas } / E P I}=\frac{p_{L P G / E P I}}{r_{L P G} \cdot T_{L P G / E P I}}
$$

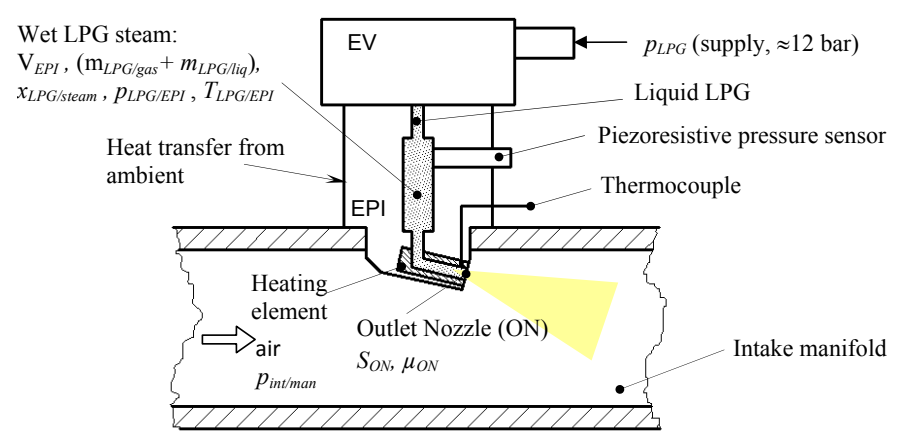

FIGURE 1: Injector for liquid LPG injection. Heating element in the lower part of the EPI is for heating the outlet nozzle only (precaution against icing on the $\mathrm{ON}$, heat transfer from the heating element to the main part of the EPI is minimal).

OBRÁZEK 1: Schéma vstřikovače kapalného LPG. Topný element v nejspodnější partii koncové části vstřikovače (EPI) je pro ohřev výtokové trysky (ON) jako opatření proti vzniku námrazy na ON, prostup tepla do hlavní části EPI je minimální.

For the expression of the proportion of vaporized LPG in the EPI the following relationship for saturation of the wet LPG steam was used:

$$
\begin{aligned}
& x=k_{\text {evapor }} \cdot\left(1-\frac{\rho_{L P G / E P I}}{\rho_{L P G / \text { liquid }}}\right), \\
& \left(\rho_{L P G / \text { liquid }} \cong 550 \mathrm{~kg} / \mathrm{m}^{3}\right) .
\end{aligned}
$$

The value of the evaporation correction factor $k_{\text {evapor }}$ is determined by calibration of the computational model using the measured traces of LPG pressure inside the EPI.

The thermal balance for the wet LPG steam in the EPI (simplified, ignoring the effect of the specific thermal capacities of the gas and liquid phases on temperature) comprises the following:

- Heat contained in the $L P G\left(L P G_{\text {liq }}+L P G_{\text {gas }}\right)$ at the start of each calculation step $\Delta \tau(0.2 \mathrm{~ms})$ in the EPI. 


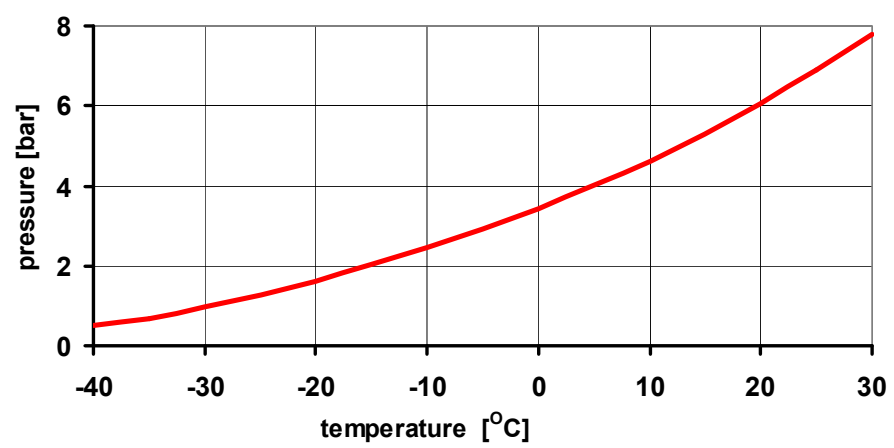

FIGURE 2: The pressure of saturated LPG steam as a function of temperature for the composition Propane and Butane 50/50 at LPG [2]. OBRÁZEK 2: Závislost tlaku nasycených par LPG na teplotě pro obsah propanu a butanu v LPG 50/50 [2].

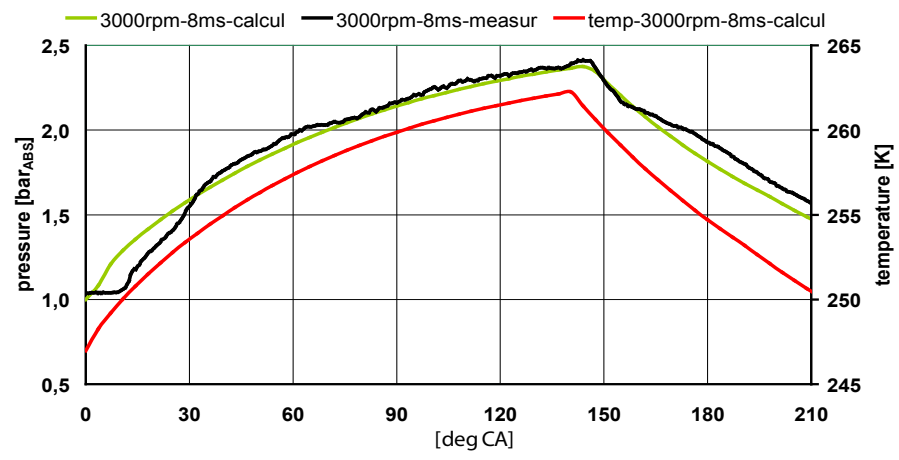

FIGURE 3: The calculated and measured plots of LPG pressure inside the EPI illustrate acceptable correlation in describing the injection mechanism for liquid LPG (the differences at the initial phase of liquid LPG charging from EV to EPI are likely caused by a transport delay between $\mathrm{EV}$ and $V_{E P I}$ inside the EPI).

OBRÁZEK 3: Vypočtený a změřený průběh tlaku LPG v EPI dokumentuje prijijatelnou správnost popisu mechanizmu vstřikování kapalného LPG (rozdíl v počáteční fázi dodávky výtoku LPG z EV do EPI je zřejmě důsledkem dopravního zpoždění mezi $\mathrm{EV}$ a objemem $V_{E P I}$ uvnitř $\left.\mathrm{EPI}\right)$.

- Heat contained in the liquid LPG fed into the EPI in the quantity $\Delta m_{L P G / l i q}$ at the start of each calculation step.

- Ambient heat which transfers to the LPG inside EPI at each calculation step.

- Heat needed for LPG evaporation in the given calculation step for the estimated saturation of wet LPG steam.

- The temperature of the wet LPG steam is determined from the thermal balance for LPG inside the EPI. The pressure of wet LPG steam inside the EPI is determined by computing the relationship between temperature and pressure for saturated LPG steam (the relationship between temperature and pressure of saturated LPG steam is shown in Figure 2 for an LPG composition of propane and butane 50/50).

Figure 2 clearly illustrates the problem associated with the injection of liquid LPG into the engine intake manifold. After outflow of the liquid LPG from the EV into volume $V_{E P I}$ in the EPI, the LPG pressure decreases rapidly from $p_{L P G / l i q} \cong 12$ bar to $p_{L P G / V_{E P I}} \cong 1$ bar (according to operating conditions of an $\mathrm{SI}$ engine the LPG pressure in the EPI drops to the pressure in the intake manifold $p_{\text {int man }}$ ) and the LPG temperature drops to $t_{L P G / V_{E P I}} \approx-30^{\circ} \mathrm{C}$ (or lower) at start of intensive LPG evaporation.

- The outflow of the wet LPG steam into the intake manifold is treated as an outflow of a gas. Only saturated steam has the properties of gas, the outflow of which carries LPG droplets. In the calculation, the elementary quantities carried in the liquid phase (droplets) are included using the proportion of vaporized LPG (quantity $x$ for the saturation of wet steam) inside the EPI.

$$
\Delta m_{L P G / O N}=\mu_{O N} \cdot S_{O N} \cdot \frac{1}{x} \cdot w_{L P G g a s / O N} \cdot \rho_{\text {LPGgas } / O N} \cdot \Delta \tau(4)
$$

Substitution of the relationships for the velocity and density of LPG gaseous state at the ON (respecting subcritical and critical outflow) gives the following - see formula (5).

- The calculation procedure repeats through the injection of the whole liquid LPG charge from the EV to the EPI up the outflow of wet LPG steam into the intake manifold.

The computational model conforms relatively well with the results of measured LPG pressure plots inside the EPI for the value of the evaporation correction factor $k_{\text {evapor }} \cong 0.8$. Figure 3 shows the calculated plot of LPG pressure and temperature inside the EPI and the measured plot of LPG pressure inside the EPI. The LPG temperature plot inside the EPI is the outcome of thermal balance; the plot of calculated pressure into EPI corresponds to the relationship between temperature $t$ and pressure $\rho$ in Figure 2 .

Note: The LPG pressure inside the EPI was measured on the injector inserted into a model intake manifold connected to the suction of a diesel engine (the intake air pressure in the model intake manifold was practically constant, $p_{\text {intman }} \cong 1$ bar): the diesel engine was used as a generator for the air flow in the model intake manifold and also ensured the smooth combustion of the combustible mixture from the model intake manifold.

$$
\Delta m_{L P G / O N}=\mu_{O N} \cdot \frac{S_{O N}}{x} \cdot \sqrt{\frac{2 \cdot \kappa_{L P G}}{\kappa_{L P G}-1} \cdot \frac{p_{L P G / E P I}^{2}}{r_{L P G} \cdot T_{L P G / E P I}} \cdot\left(\frac{p_{\text {in } / \operatorname{man}}}{p_{L P G / E P I}}\right)^{\frac{2}{\kappa_{L P G}}} \cdot\left[1-\left(\frac{p_{\text {in } / \operatorname{man}}}{p_{L P G / E P I}}\right)^{\frac{\kappa_{L P G}-1}{\kappa_{L P G}}}\right]} \cdot \Delta \tau
$$


The model calculations were primarily for research, but the results were also used for EPI design with heating of the outlet nozzle and subsequently for experimental research on an SI engine.

\section{EXPERIMENTAL RESEARCH ON SI ENGINE WITH MPI OF LIQUID STATE LPG}

Experimental research was performed on a vehicle $\mathrm{SI}$ engine type EA111.03E (three-cylinder engine with $1.2 \mathrm{dm}^{3}$ total displacement). Standard as well as an advanced measuring technique normally used for overall research of an SI engine on a test bench (high pressure indication with on-line thermodynamic analysis, exhaust emissions, visual monitoring of liquid state LPG injection into the suction manifold).

LPG Injectors and EPI with heating of outlet nozzle (own design of EPI) were installed into the intake manifold. A VIALLE LPG fuel system was used for alternative engine running on petrol or LPG. Figures 4 and 5 show the lay-out of the EPI on intake manifold and detail of the EPI design.

The engine was set to run on LPG based on the original ECU setting for petrol fuel. The ignition timing for the engine running on LPG was the same as for petrol fuel (BA95). Based on experience from previous research on a similar engine [3], in the higher-load regime the engine EA111.03E-LPG across all revolutions was set to a less rich mixture than the ECU would set as standard when running on BA95 (the start of fuel inject was almost identical for both LPG and BA95, in the ECU for LPG it was only possible to adjust to a limited extent using a correction period for opening the LPG injectors, thus the size of the injected LPG dose).

When adjusting and taking readings from the engine, on-line diagnostics was performed using high-pressure indication. For all cylinders the pressure plots have very similar characteristic parameters both running on LPG and on BA95. The cases of

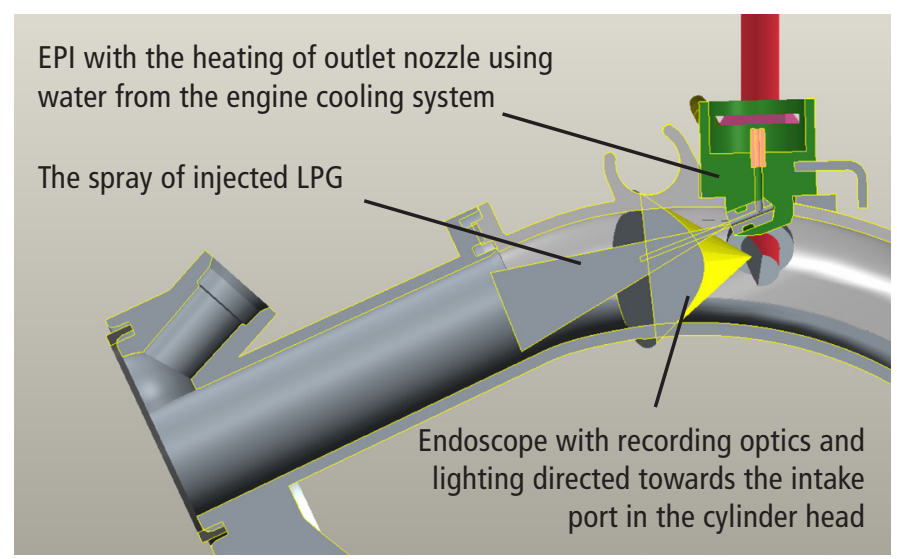

knocking were of lower intensity for the engine running on LPG (in comparison to running on BA95), and the knocking was suppressed by the standard activity of the ECU (decreasing spark advance - checking by reading recorded data from ECU).

The results of exhaust emission measurements on the engine EA111.03E-LPG running on both LPG and BA95 conform to the former emissions measurements on engine EA111.03D-LPG [3]. The differences in the results of recorded measurements are between running the EA111.03E-LPG engine on LPG or BA95, and they correspond to the somewhat different engine settings running on LPG and BA95.

The graphs below show the important characteristics of the engine EA111.03E-LPG running on petrol and on LPG.

Figure 6 shows adjustment of mixture richness for engine EA111.03E-LPG running both on LPG and BA95 at full load and varying speeds. The lower enrichment for the engine running on LPG causes an increase in the exhaust gas temperature at higher engine speed ( $t$ _exh/Bcat - temperature before catalyzer). This increased temperature is of no risk to the catalyzer.

Figure 7 shows that the power output of SI engine EA111.03E-LPG with mixture formed by MPI liquid LPG is identical to or higher than that achieved by the engine running on petrol (the engine power on LPG is about $2 \%$ higher at mid operating speed). Engine EA111.03E-LPG has a higher overall efficiency on LPG due to the less rich mixture used in comparison with petrol running. The higher total efficiency of the engine running on LPG and the somewhat lower carbon content in LPG (compared to the carbon content in petrol) contributes to a lower production of carbon dioxide $\mathrm{CO}_{2}$ (the content of $\mathrm{CO}_{2}$ in a dry sample of exhaust gas at full load across the speed range for the engine running on BA95 was in the range 13.2-10.4\%, and for engine running on $L P G$ in the range $12.9-9.2 \%$ ).

The research program on the EA111.03E-LPG engine is also focused on a detailed study of injection of liquid state LPG into

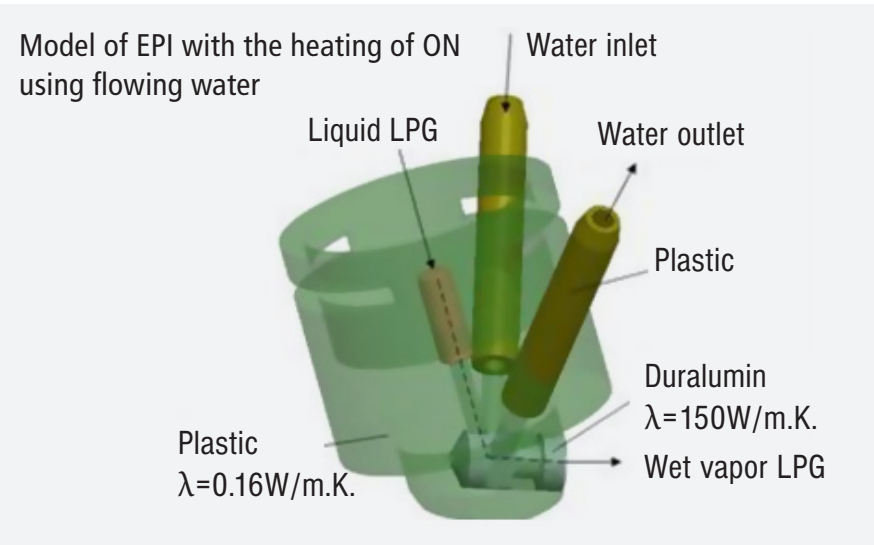

FIGURE 4: Model of EPI location on the engine intake manifold. The bottom part of EPI with the ON is designed to minimize cross-section contraction in the intake manifold. The $\mathrm{ON}$ is heated by flowing water (from the engine cooling system) around the front surface of the ON.

OBRÁZEK 4: Model umístění EPI do sacího potrubí motoru. Konstrukce spodní části EPI s ON zajištuje minimální omezení průtočného průřezu v sacím potrubí motoru. Ohřev $\mathrm{ON}$ je proveden průtokem vody (z chladicího systému motoru) kolem čelní plochy ON. 


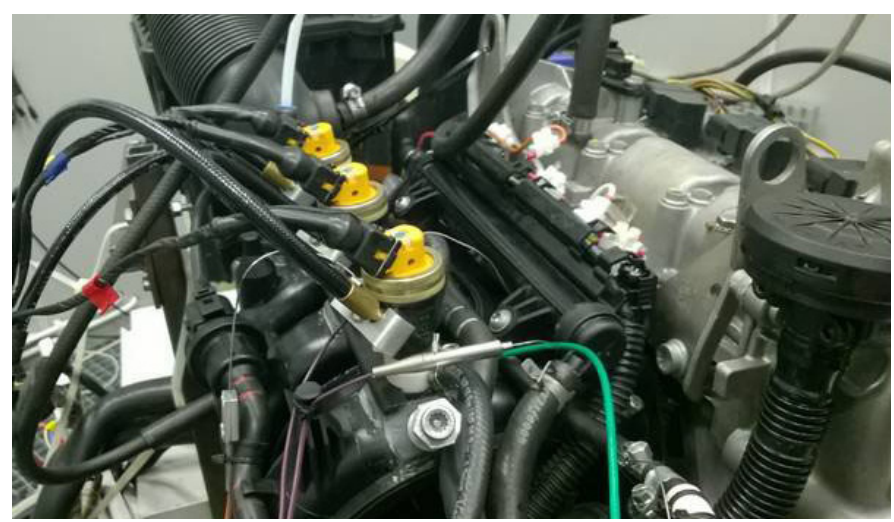

FIGURE 5: View of the intake manifold with the LPG injectors. Input of liquid LPG is to EV (yellow "cup"). Input pressure of liquid LPG is 5 bar higher than the pressure in the LPG tank (the LPG pump in the tank, for the laboratory conditions, increases the pressure to $p_{L P G / i q} \cong 12 \mathrm{bar}$ ). $E V$ are fixed to EPI on the engine intake manifold. OBRÁZEK 5: Pohled na sací potrubí motoru se vstřikovači LPG. Př́ivod kapalného LPG je do EV (žluté "kloboučky"). Vstupní tlak LPG do EV je 05 bar větší než tlak LPG v nádrži (čerpadlo LPG v nádrži zvyšuje v podmínkách zkušebny tlak LPG do EV na $p_{L P G / i q} \cong 12$ bar). EV jsou upevněny do EPI na sacím potrubí.

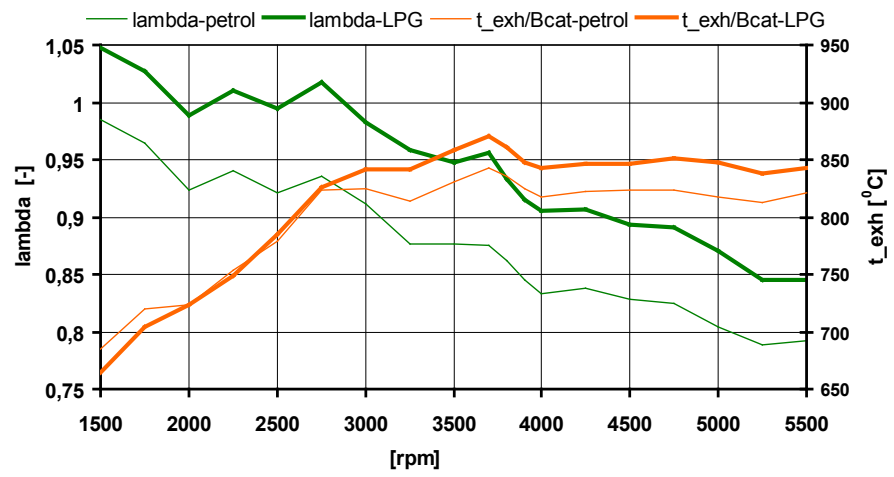

FIGURE 6: The mixture richness and exhaust gas temperature (t_exh/Bcat - temperature before catalyzer) of engine EA111.03E-LPG at full load running on LPG or BA95.

OBRÁZEK 6: Bohatost směsi a teplota výfukových plynů (t_exh/Bcat teplota před katalyzátorem) motoru EA111.03E-LPG v režimech vnější otáčkové charakteristiky při provozu na LPG nebo BA95

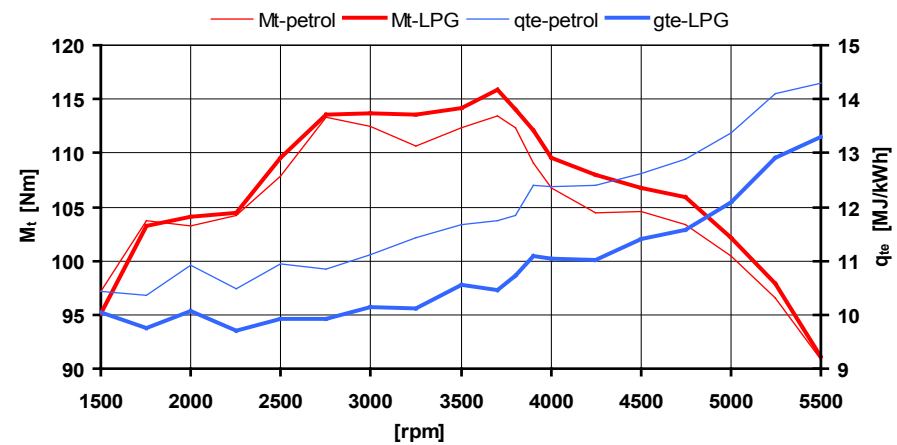

FIGURE 7: The plots of torque moment and specific heat (energy) consumption of engine EA111.03E-LPG running on LPG or BA95. OBRÁZEK 7: Průběhy točivého momentu a měrné spotřeby tepla motoru EA111.03E-LPG prí provozu na LPG nebo BA95. the intake manifold. Figures 8 and 9 show selected results from the measuring of temperature on the front surface of the $\mathrm{ON}$, and pressure plots of wet LPG steam inside the EPI.

Figure 8 plots the temperature on the front surface of the ON for varying loads of the EA111.03E-LPG engine at $3700 \mathrm{rpm}$. Temperatures on surface of the $\mathrm{ON}$ are in the range $65-75^{\circ} \mathrm{C}$ for the engine running on petrol. The temperature decreases on the front surface of the $\mathrm{ON}$ when the engine runs on LPG. With heating of the $\mathrm{ON}$, the temperature on its front surface is $35^{\circ} \mathrm{C}$ at very low engine load, which drops to $5^{\circ} \mathrm{C}$ at full engine load. The heating of the $\mathrm{ON}$ by flowing water around the front of the $\mathrm{ON}$ has sufficient effect. Without heating of the $\mathrm{ON}$, the temperature declines sharply on the front surface of the $\mathrm{ON}$ to below freezing point when the engine is run on LPG.

The seemingly illogical plot of temperature with respect to engine load is determined by the relationship between the evaporating pressure and evaporating temperature of $L P G$ - see plots of measured LPG pressure in the EPI in Figure 9: at very low engine load, the pressure in the intake manifold is about

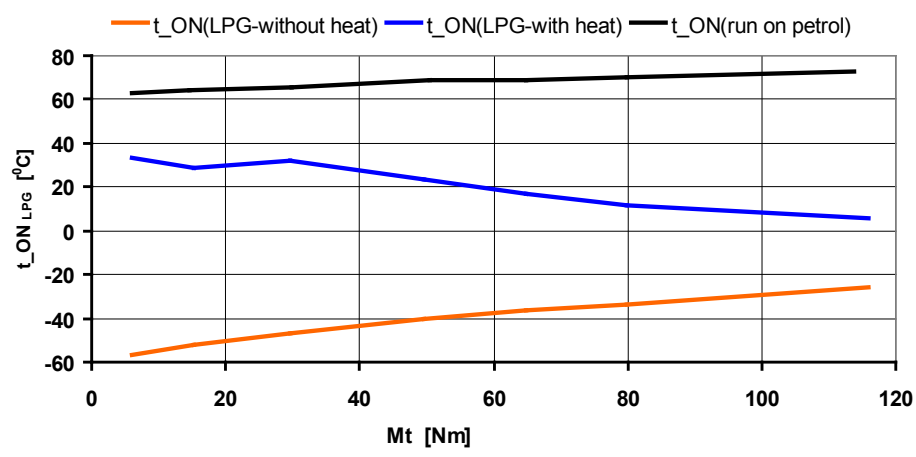

FIGURE 8: Plots show the temperature on the front surface of the ON in relation to engine load (EA111.03E-LPG) at $3700 \mathrm{rpm}$. OBRÁZEK 8: Průběhy teplot na čele výtokové trysky ON v zatěžovací charakteristice motoru EA111.03E-LPG prii 3700 1/min.

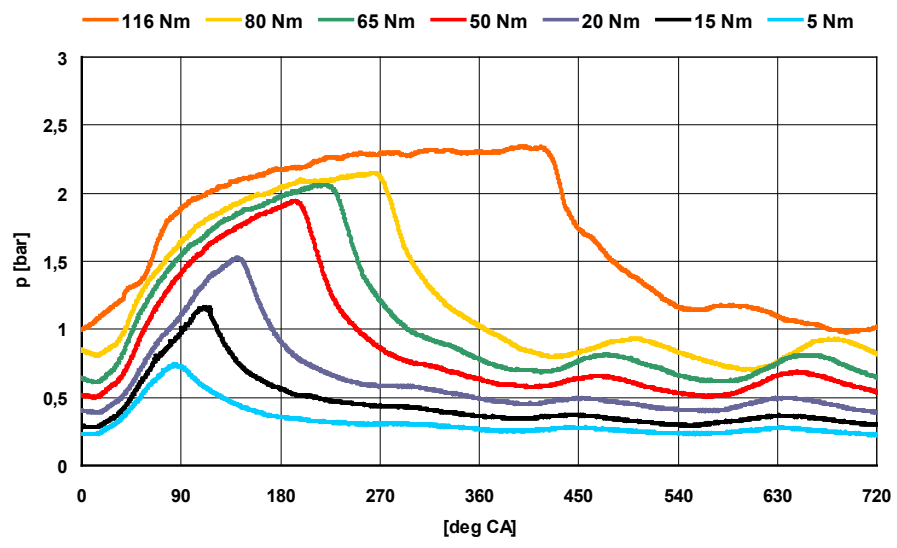

FIGURE 9: Plots of LPG pressure inside the EPI in relation to engine load at $3700 \mathrm{rpm}$. The pressure decreases in the intake manifold under the effect of throttling back to decrease SI engine power.

OBRÁZEK 9: Průběhy tlaku LPG v EPI v režimech zatěžovací charakteristiky při otáčkách motoru 3700 1/min. Tlak v sacím potrubí motoru se snižuje účinkem škrticí klapky při kvantitativní regulaci výkonu motoru. 
0.25 bar, which corresponds to an evaporating temperature of LPG of about $-60^{\circ} \mathrm{C}$ (data according to [4]).

Figure 9 shows the recorded plots of LPG pressure inside the EPI in relation to load at $3700 \mathrm{rpm}$. The pressure decreases in the intake manifold under the effect of throttling back to decrease SI engine power. The pressure from intake manifold transfers immediately into volume $V_{E P I}$ in the EPI, and the low pressure LPG inside the EPI significantly reduces the temperature of LPG evaporation inside volume $V_{E P I}$ (i.e. the temperature of wet $L P G$ steam flowing out from the $\mathrm{ON}$ ) and if the $\mathrm{ON}$ is not heated, the temperature on the $\mathrm{ON}$ front surface drops well below freezing point. The fluctuation of measured LPG pressure inside the EPI at high engine load relates to the dynamic effects in the intake manifold.

Note 1: Figure 9 presents recorded plots of LPG pressure inside the EPI without heating of the ON. LPG pressures inside the EPI is somewhat higher when $\mathrm{ON}$ heating is applied. For example: maximum LPG pressure inside the EPI at full engine load is 2.35 bar without heating and 2.55 bar with heating of the $\mathrm{ON}$; at very low engine load the maximum pressure is $0.75 \mathrm{bar}$ without heating and 1.75 bar with heating of the ON. This is caused by change of thermal balance of LPG inside EPI, because in the approx. 8mm long channel before the ON (see injector arrangement in Figure 1) part of the heat for warming the $\mathrm{ON}$ also goes into the wet LPG steam, and this effect is greater in the case of small LPG injection charges.

Note 2: Position 0 [deg CA] in the graphs is not TDC of the crankshaft; the pressure plots of LPG inside the EPI are converted from the recording of pressure over time (the LPG injection start points are identical to the petrol ECU injection times).

\section{VISUAL INSPECTION}

\section{OF LIQUID STATE LPG INJECTION}

Visual monitoring of the injection of liquid state LPG into the intake manifold was performed using an AVL Engine VideoScope 513D. Figures 10 to 13 show selected pictures from the plot of liquid LPG injection for both very low and full engine load at mid-range operational rpm. The endoscope with lighting was used.

\section{CONCLUSION}

The experience of the authors from the Technical University of Liberec on research of a vehicle engine for alternative running on LPG with mixture forming by MPI of liquid state LPG can be summarized in the following points:

1. Heating of the end face of the $\mathrm{ON}$ with minimizing of the heat transfer to wet LPG steam before the ON is an effective method against of icing on the front ON surface.

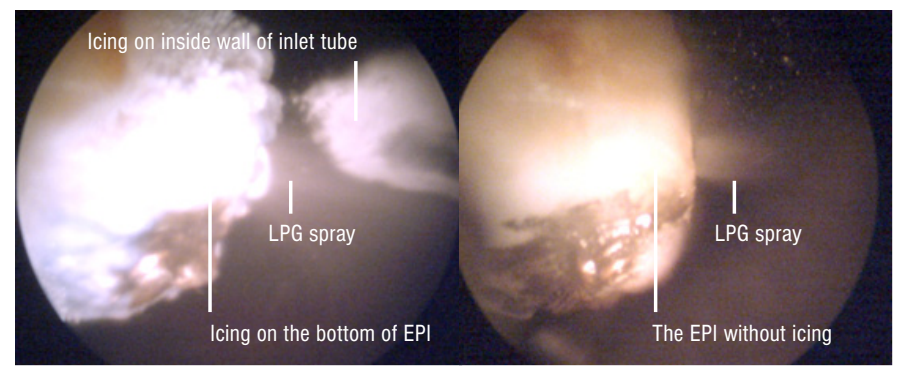

FIGURE 10: View of the injector ON, engine running on LPG (3700 rpm, $6 \mathrm{Nm}$ ). The left picture is the liquid LPG injection without ON heating, the right picture is the liquid LPG injection with ON heating. When operating without $\mathrm{ON}$ heating, icing occurs on the $\mathrm{ON}$ and on the wall inside the plastic suction manifold near the injector.

OBRÁZEK 10: Pohled na ON vstřikovače, provoz motoru na LPG (3700 1/min, 6 Nm). Snímek vlevo je vstřik LPG bez ohřevu ON, vpravo je vstřik LPG s ohřevem ON. Při provozu motoru bez ohřevu ON vzniká námraza na čelní ploše $\mathrm{ON}$ a na stěně plastového sacího potrubí v blízkosti vstřikovače LPG.

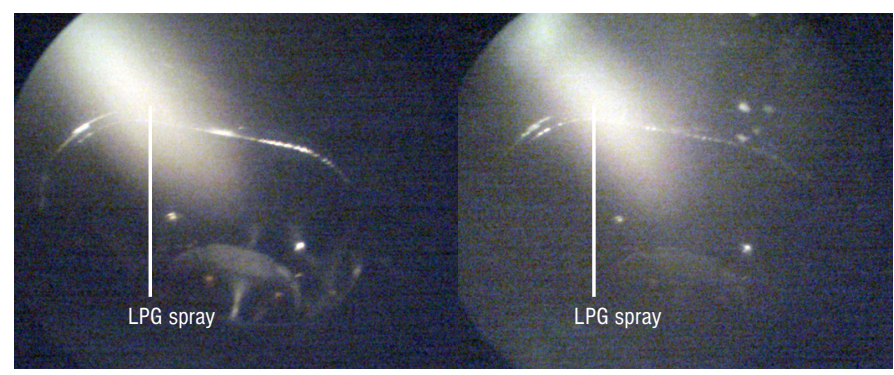

FIGURE 11: View of the intake port of cylinder head, engine running on LPG ( $3700 \mathrm{rpm}, 6 \mathrm{Nm}$ ). The left picture is the liquid LPG injection without ON heating, the right picture is the liquid LPG injection with ON heating. No icing occurs on the plastic wall inside the suction manifold near the cylinder head port at very low engine load when running on LPG.

OBRÁZEK 11: Pohled směrem k sacímu kanálu v hlavě válců, provoz motoru na LPG (3700 1/min, 6 Nm). Snímek vlevo je vstřik LPG bez ohřevu ON, vpravo je vstřik LPG s ohřevem ON. Stěna plastového sacího potrubí v blízkosti vstřikovače LPG je při provozu motoru na LPG při nízkém zatížení bez námrazy.

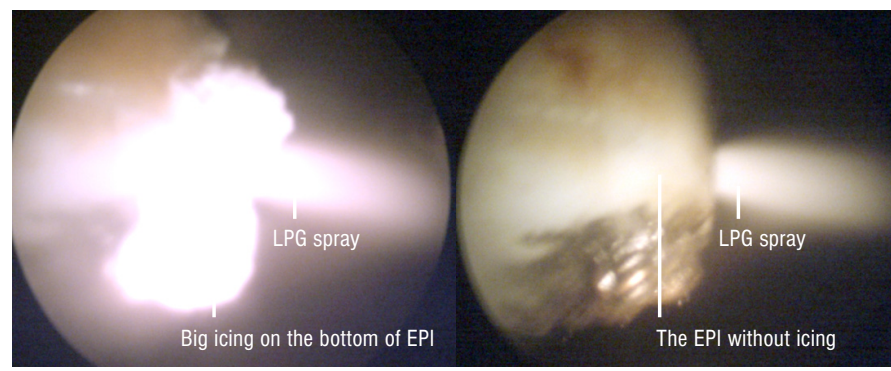

FIGURE 12: View of LPG injector ON, engine running on LPG (3700 rpm, $116 \mathrm{Nm}$ - Full load). The left picture is the liquid LPG injection without ON heating, the right picture is the liquid LPG injection with ON heating. Large icing only forms around the $\mathrm{ON}$ when running the engine on LPG without ON heating.

OBRÁZEK 12: Pohled na ON vstřikovače LPG, provoz motoru na LPG (3700 1/min, 116 Nm). Snímek vlevo je vstřik LPG bez ohřevu ON, vpravo je vstřik LPG s ohřevem ON. Velká námraza na čelní ploše ON a na stěně plastového sacího potrubí v blízkosti vstřikovače LPG vzniká pouze při provozu motoru bez ohřevu ON. 


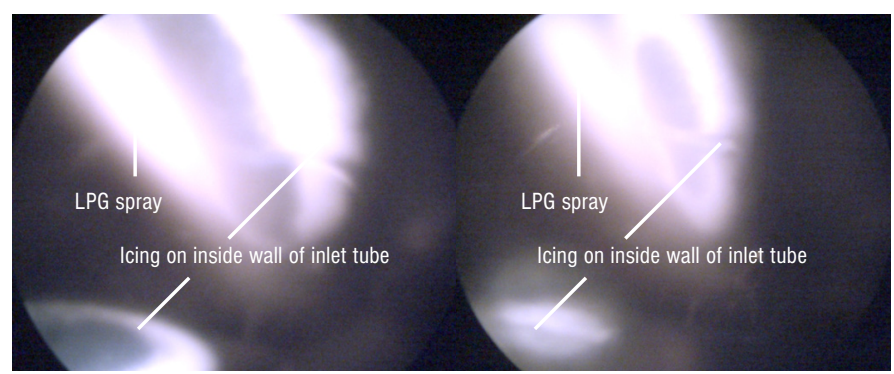

FIGURE 13: View of intake port of cylinder head, engine running on LPG (3700 rpm, $116 \mathrm{Nm}$ - Full load). The left picture is the liquid LPG injection without $\mathrm{ON}$ heating, the right picture is the liquid LPG injection with $\mathrm{ON}$ heating. Icing forms on the plastic wall inside the intake manifold near the port of cylinder head both without ON heating and with ON heating at full load with the engine running on LPG: the icing is somewhat lower with ON heating.

OBRÁZEK 13: Pohled směrem $\mathrm{k}$ sacímu kanálu v hlavě válců, provoz motoru na LPG (3700 1/min, 116 Nm-100\% zatížení). Snímek vlevo je vstřik LPG bez ohřevu ON, vpravo je vstřik LPG s ohřevem $O N$. Na stěně plastového sacího potrubí v blízkosti sacího kanálu v hlavě válců se v režimu plného zatížení motoru tvoří námraza jak bez ohřevu ON, tak s ohřevem ON: při provozu s ohřevem ON je ale námraza na plastovém potrubí v blízkosti sacího kanálu poněkud menší.

2. Research of liquid state LPG injection into the intake manifold shows that dominant factor for trouble-free running of an engine on LPG is the suitable design of the EPI inside the engine intake manifold. Dimensions and insertion of bottom EPI part into the intake manifold must minimize the cross-section contraction in the intake manifold (particularly for a naturally aspirated SI engine).

3. The outflow of wet LPG steam must be directed to the central area of the flow system inside the intake manifold. Impact of wet LPG steam on the inside wall of the intake manifold risks icing on the wall. The parameters of the liquid state LPG injection can be improved using an $\mathrm{EV}$ with a higher flow rate and shortened time of EV opening. The pressure and temperature of LPG inside the EPI is thereby increased significantly, and both the speed of LPG spray outflow from the $\mathrm{ON}$ and the range of compact wet steam spray are increased. This reduces the potency of impact of the wet steam spray on the inside wall of the plastic intake manifold, and ice formation is thus suppressed.

\section{ACKNOWLED GEMENTS}

This research has been realized using the support of Technological Agency, Czech Republic, Programme of Centers Competence, Project \# TE01020020 Josef Božek Centre for Automotive Industry. This support is gratefully acknowledged.
LIST OF NOTATIONS AND ABBREVIATIONS

BA95 Petrol Fuel (Octane Number 95)

ECU Electronic Control Unit

EPI End Part of Injector

EV Electromagnetic Valve

LPG Liquefied Petroleum Gas

MPI Multi Point Injection

ON Outlet Nozzle

SI Spark Ignition

TDC Top Dead Center

$k_{\text {evapor }} \quad$ correction factor of evaporation

$m_{L P G / \text { gas } / E P I}$ Mass gaseous LPG inside EPI

$m_{L P G / l i q / E P I}$ Mass liquid LPG inside EPI

$p_{\text {intman }} \quad$ Air pressure inside intake manifold

$p_{L P G / i q / E V} \quad$ LPG pressure inside EV

$p_{L P G / E P I} \quad$ LPG pressure inside EPI

$q_{t} \quad$ Specific heat consumptin

$\rho_{L P G} \quad$ Gas constant of LPG

$x_{L P G / \text { tseam/EPI }}$ Factor of wet steam LPG saturation inside EPI

$S_{O N} \quad$ Flow area of ON

$T_{L P G / E P I} \quad$ LPG temperature inside EPI

$\mathrm{V}_{E P I} \quad$ Volume inside EPI

$D m_{L P G / l i q}$ Mass elementary quantities LPG from EV to EPI

$D t \quad$ Time of calculation step

$k_{L P G} \quad$ Adiabatic exponent of gaseous LPG

$\mu_{O N} \quad$ Flow coefficient of ON

$\rho_{\text {LPG/FPI }} \quad$ Density of wet steam LPG inside EPI

$\rho_{L P G / / g a s / E P I}$ Density of saturated steam LPG inside EPI

$\rho_{L P G / l i q / E P I}$ Density of droplets LPG disspersed inside EPI

$\rho_{\text {LPG/liquid }}$ Density of liquid LPG $\left(\rho_{\text {LPG/liquid }}=550 \mathrm{~kg} / \mathrm{m}^{3}\right)$

\section{REFERENCES}

[1] Beroun, S., Brabec, P., Dittrich, A., Dráb, O., Nguyen, T., T.: Computational Modeling of the liquid LPG Injection into the suction Manifold of an SI Vehicle Engine. Applied Mechanics and Materials Vol. 390 (2013) pp. 355-359. ICMAE 2013, Moscow.

[2] Bruner, G., Chmela, F., Pachta-Reyhofen, G.: Flüssiggasbetrieb bei Omnibusen. Gräf \& Stift and MAN, Wien.

[3] Mareš, J., Beroun, S., Blažek, J., Holubec, R, : Automotive Engine with Injection of the Liquid LPG into the Inlet Manifold. Journal of Kones, Powertrain and Transport, Vo.14, No.3 2007.

[4] Šesták, J., Bukovský, J., Houška, M.: Tepelné pochody, Transportní a termodynamická data. Skripta ČVUT v Praze, 2004. ISBN 80-01-02934-4. 